\section{Low frequency of microsatellite instability in BRCA1 mutated breast tumours}

EDITOR-BRCA1 is one of the major breast and ovarian cancer susceptibility genes. Many studies have suggested that the BRCA1 protein is multifunctional. Notably, it may play a role in DNA repair, especially in double strand break (DSB) DNA repair by homologous recombination because (1) BRCA1 acts in association with $\operatorname{Rad} 51,{ }^{12}$ (2) DNA damage induces its phosphorylation and delocalisation from nuclear foci to the DNA replication forks, ${ }^{3}$ and (3) it contains a zinc finger domain that interacts with BARD1, an effector of DNA repair, ${ }^{4}$ and two BRCT (BRCA1 C-terminal) domains which are found in various proteins implicated in DNA repair ${ }^{6}$ (fig 1A).

Among the various genetic alterations found in breast tumours, one is called microsatellite instability (MI). MI has been shown in a small fraction of sporadic breast tumours, varying from 0 to $30 \%,{ }^{7}$ and in familial breast tumours conflicting results have been reported with a MI+ tumour frequency of $0 \%(0 / 15)$ according to Lothe et $a l^{8}$ and $83 \%(15 / 18)$ according to Glebov et al. ${ }^{9}$

$\mathrm{MI}$ is characterised by expansion or contraction in one or both alleles of some microsatellites in tumour DNA. First described in hereditary non-polyposis colorectal cancer (HNPCC) and in tumours associated with the HNPCC spectrum, ${ }^{10} \mathrm{MI}$ is usually the result of defects in DNA mismatch repair. The resulting phenotype is called replication error + (RER+), as in nearly all RER+ HNPCC tumours DNA mismatch repair genes ( $M M R$ genes) are mutated. However, in breast tumours, it seems that the nature of instability differs from that described for HNPCC since (1) MI occurs in a lower number of markers, (2) the microsatellite loci affected are mainly trinucleotides and tetranucleotides, ${ }^{112}$ and (3) instability is characterised by the occurrence of new allele(s) very different in size from the normal ones. ${ }^{13}$ Since no mutation in the $M M R$ genes has been found in breast tumours, it has been proposed that other genes, still unknown and probably implicated in a DNA repair pathway different from mismatch repair, may be involved in this particular type of MI.

In the two studies on familial breast tumours, no information was provided concerning the hereditary predisposition gene implicated in the families, but the analysis of Glebov et $a l^{9}$ shows frequent loss of heterozygosity (LOH) at the markers surrounding the $17 \mathrm{q} 21$ region which contains the BRCA1 locus.

Following these observations, it may be hypothesised that loss of BRCA1 function could lead to abnormal homologous recombination, resulting, when DSB takes place at microsatellite loci, in changes in the repeat number, that is, MI. Therefore, it would be of interest to know whether MI is found in familial BRCA1 tumours, where BRCA1 function is lost consecutively to a germline mutation that inactivates one allele and, in $86 \%$ of tumours, to the somatic loss ( $\mathrm{LOH}$ ) of the wild type allele. $^{14}$

We report here the results of the relationship between $B R C A 1$ germline mutation, $\mathrm{MI}$ status, and $\mathrm{LOH}$ at the $B R C A 1$ locus in $13 B R C A 1$ mutated breast tumours from 10 unrelated French families.

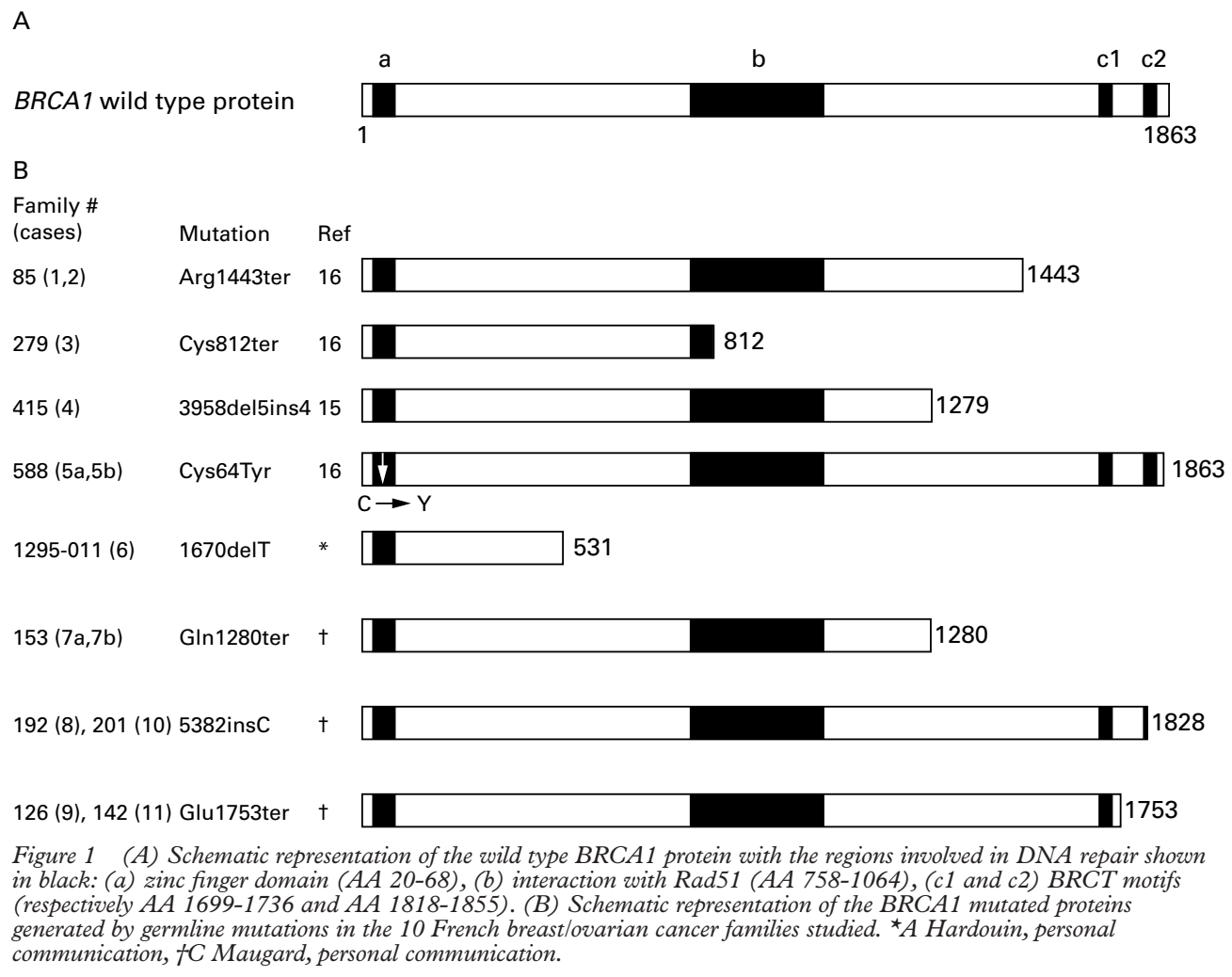




\begin{tabular}{|c|c|c|c|c|c|c|c|c|c|c|c|c|c|c|c|}
\hline \multirow{3}{*}{$\begin{array}{l}\text { Chromosome } \\
1 \mathrm{q} 21-23\end{array}$} & \multirow{3}{*}{$\begin{array}{l}\text { Locus } \\
\text { APOA2 }\end{array}$} & \multirow{3}{*}{$\begin{array}{l}\text { Family } \\
\text { Repeat } \\
\text { CA }\end{array}$} & \multicolumn{2}{|c|}{85} & \multicolumn{2}{|c|}{279415} & \multicolumn{3}{|c|}{$\begin{array}{ll} & 1295 \\
588 & -011\end{array}$} & \multicolumn{2}{|c|}{153} & \multicolumn{2}{|c|}{192126} & \multicolumn{2}{|c|}{201142} \\
\hline & & & 1 & 2 & 3 & $\overline{4}$ & $5 a \dagger$ & $\overline{5 b \dagger}$ & 6 & $7 a \neq$ & $\overline{7 b \neq}$ & 8 & 9 & $\overline{10}$ & 11 \\
\hline & & & & & & & & & & & & & & & \\
\hline 2 Cen & 4DO7 & GGAA & & ND & & & & & ND & & & & & ND & \\
\hline $11 \mathrm{p} 15.1$ & D11S988 & CA & ND & & & & & & & & & & & & \\
\hline $17 q 21 *$ & Mfd855* & CA & 0 & 0 & 0 & 0 & 0 & 0 & 0 & $\oslash$ & $\oslash$ & $\emptyset$ & 0 & $\mathrm{MI}$ & 0 \\
\hline $17 q 21 *$ & $\mathrm{D} 17 \mathrm{~S} 1322^{*}$ & CAA & 0 & 0 & $\oslash$ & 0 & 0 & 0 & 0 & $\oslash$ & $\oslash$ & 0 & 0 & $\oslash$ & 0 \\
\hline $17 q 21 *$ & D17S1323* & CA & 0 & 0 & $\mathrm{MI}$ & 0 & 0 & 0 & $\emptyset$ & $\oslash$ & $\oslash$ & 0 & 0 & $\emptyset$ & $\oslash$ \\
\hline $19 q 13.3$ & DM-1 & CAG & & & & & & & & & & & & $\mathrm{MI}$ & \\
\hline $21 q 21$ & 2EO2 & GGAA & & & & & & & & & & & & & \\
\hline Xq11-12 & $A R$ & CAG & & & & & & & ND & & & & & & \\
\hline $2 p 22-21$ & Bat-26 & A & & & & & & & & & & & & & \\
\hline
\end{tabular}

Figure $2 M I$ and LOH status at the BRCA1 locus in familial BRCA1 tumours. *Intragenic markers at the BRCAI locus, $\uparrow$ samples $5 a$ and $5 b$ correspond to two tumours in a patient with a multifocal breast cancer, $\ddagger$ samples $7 a$ and $7 b$ correspond to two tumours in a patient with bilateral breast cancer, open circle: informative, no loss, closed circle: informative, loss, hatched circle: not informative, grey square: no allele length alteration, MI: altered length of allele $(s)$ in tumour DNA, that is, microsatellite instability, ND: not determined because no amplification was obtained with the tumour $D N A$.

Germline mutations were found by direct sequencing or by the protein truncation test followed by sequencing ${ }^{15} 16$ (C M Maugard, personal communication, A Hardouin, personal communication). Nine mutations generate truncated proteins and one is a missense mutation which induces a critical change of amino acid in the zinc finger domain (fig 1B). All these alterations disrupt at least one of the four BRCA1 DNA repair domains. Tumour DNA was obtained from paraffin embedded tissues fixed in formalineosin after microdissection of the tumour foci. The corresponding normal DNA was obtained from peripheral blood lymphocytes. DNA extraction was performed as described previously. ${ }^{17}$ Microsatellite analysis was performed with 10 markers, located on eight different chromosomes (fig 2). The majority of the microsatellites studied were tri- and tetranucleotide repeats which have previously shown instability in breast tumours. Three intragenic markers at the $B R C A 1$ locus have been used to identify both $\mathrm{MI}$ and $\mathrm{LOH}$ of a BRCA1 allele. The Bat-26 repeat was used as a marker for the RER+ phenotype. ${ }^{18}$ PCR conditions and microsatellite size analysis (fluorescent technology using a 373A DNA Sequencer, Perkin Elmer) have been described previously. ${ }^{17}{ }^{18}$

Among the 10 informative cases (10/13), nine tumours (90\%) exhibited $\mathrm{LOH}$ at one or more intragenic BRCA1 markers (fig 2), confirming the anti-oncogenic nature of the $B R C A 1$ gene. Only one informative tumour has lost no marker. Among the 13 tumours, two cases (tumours 3 and $10,15.4 \%$ ) showed MI. This result has been confirmed by duplicate experiments on the same tumour DNA and on an independent extraction. MI corresponds to the appearance of a new allele in tumour DNA different in size from the normal alleles, that is, tumour 3 D17S1323 -2 bp, tumour $10 \mathrm{Mfd} 855-6 \mathrm{bp}, \mathrm{DM}-1+15 \mathrm{bp}$. This does not confirm the frequency of instability observed by Glebov et $a l,{ }^{9}$ but, since no information concerning the hereditary predisposition was provided, it is possible that the familial tumours studied were not linked to the $B R C A 1$ gene.

It is noteworthy that the mutation identified in tumour 3 led to a protein lacking both BRCT domains and part of the Rad51 interacting region. It is conceivable that this more severe alteration explains the presence of $\mathrm{MI}$, in comparison with proteins lacking only the BRCT domains. Nevertheless, tumour 10, which shows $\mathrm{MI}$ at two loci, lacks only half of the BRCT $\mathrm{c} 2$ domain and in tumour 6, which lacks all BRCT and Rad51 interaction domains, no MI was found. Finally, as contraction of the Bat-26 marker is found in nearly all RER+ tumours, ${ }^{18} 19$ the absence of instability at this locus in our tumours suggests that none of these exhibit a RER+ phenotype. Thus, it is possible that the observed instabilities may be fortuitous events.

In conclusion, $\mathrm{MI}$ seems to correspond to a rare event in $B R C A 1$ breast tumours and the frequency found (15.4\%) is similar to that previously reported in sporadic breast cancers. ${ }^{17}$ Our results suggest that MI in breast tumours may not be attributable to the inactivation of the potential $B R C A 1$ DNA repair function. Nevertheless, loss of the $B R C A 1$ DNA repair function might favour another type of genomic instability, leading either to activation of oncogenes or inactivation of anti-oncogenes, in agreement with the putative caretaker function of the $B R C A 1$ gene. ${ }^{20}$

We are grateful for the assistance of Christiane Jullien in handling blocks and preparing histological sections and to Dr M Kuiper for critical review of the manuscript. This work was supported by the Ligue Nationale Française Contre le Cancer and its Comité du Puy-de-Dôme.

CATHERINE VAURS-BARRIÈRE* FRÉDÉRIQUE PENAULT-LLORCA† VALÉRIE LAPLACE-MARIEZE* NADĖGE PRESNEAU* CHRISTINE M MAUGARD MARYSE FICHES AGNÈS HARDOUIN YVES-JEAN BIGNON*

*Laboratoire d'Oncologie Moléculaire, CRI 9502 \& EA 2145, Centre fean Perrin, 58 Rue Montalembert, BP 392, 63011 Clermont-Ferrand Cedex 01, France

†Service d'Anatomie et Cytologie Pathologiques, Centre fean Perrin, 63011 Clermont-Ferrand Cedex 01, France

$\ddagger$ Centre René Gauducheau, Bd F Monod, 44805 St Herblain, France

\Service d'Anatomie Pathologique, CHU Nantes, Hopital G $\mathcal{E} R$

Laënnec, 44093 Nantes Cedex 01, France

-Centre François Baclesse, Route de Lion-sur-Mer, BP 5026, 14076 Caen Cedex 5, France

Correspondence to: Dr Bignon, Yves-Jean.Bignon@cjp.u-clermont1.fr

1 Scully R, Chen J, Plug A, Xiao Y, Weaver D, Feunten J, Ashley T, Livingston DM. Association of BRCA1 with Rad51 in mitotic and meiotic cells. Cell 1997;88:265-75.

2 Scully R, Chen J, Ochs RL, Keegan K, Hoekstra M, Feunteun J, Livingston DM. Dynamic changes of BRCA1 subnuclear location and phosphorylation state are initiated by DNA damage. Cell 1997;90:425-35.

3 Hendrickson EA. Cell-cycle regulation of mammalian double-strand-break repair. Am F Hum Genet 1997;61:795-800.

repair. Am f Hum Genet 1997;61.795-800. Phung A, Xu XI Yang MCW, Hwang LY, Bowcock AM, Baer R. Identification of a RING protein that Hwang LY, Bowcock AM, Baer R. Identification of a RING protein that
can interact in vivo with the BRCA1 gene product. Nat Genet 1996;14:43040 .

5 Callebaut I, Mornon JP. From BRCA1 to RAP1: a widespread BRCT module closely associated with DNA repair. FEBS Lett 1997;400:25-30. 
6 Koonin EV, Altschul SF, Bork P. BRCA1 protein products: functional motifs. Nat Genet 1996;13:266-7.

7 motifs. Nat Genet 1996;13:266-7. in human carcinogenesis? Bull Cancer 1997;84:1061-71.

8 Lothe RA, Peltomaki P, Meling GI, Aaltonen LA, Nystrom-Lahti M, Pylkkänen L, Heimdal K, Andersen TI, Moller P, Rognum TO, Fossa SD, Haldorsen T, Langmark F, Brogger A, de la Chapelle A, Borresen AL. Genomic instability in colorectal cancer: relationship to clinicopathological variables and family history. Cancer Res 1993;53:5849-52.

9 Glebov OK, McKenzie KE, White CA, Sukumar S. Frequent p53 gene mutations and novel alleles in familial breast cancer. Cancer Res 1994;54:3703-9.

10 Aaltonen LA, Peltomaki P, Leach FS, Sistonen P, Pylkkanen L, Meckline JP, Jarvinen H, Powell SM, Jen J, Hamilton SR, Petersen GM, Kinzler KW, Volgestein B, de la Chapelle A. Clue to the pathogenesis of familial colorectal cancer. Science 1993;260:812-16.

11 Jönsson $\mathrm{M}$, Johannsson $\mathrm{O}$, Borg A. Infrequent occurrence of microsatellite instability in sporadic and familial breast cancer. Eur $\mathcal{f}$ Cancer instability in sp

12 Wooster R, Cleton-Jansen AM, Collins N, Mangion J, Cornelis RS, Cooper CS, Gusterson BA, Ponder BAJ, VonDeimling A, Wiestler OD, Cornelisse CJ, Devilee P, Stratton MR. Instability of short tandem repeat (microsatelCJ, Devilee P, Stratton MR. Instability of short tan

13 Paulson TG, Wright FA, Parker BA, Russack V, Wahl GM. Microsatellite instability correlates with reduced survival and poor disease prognosis in breast cancer. Cancer Res 1996;56:4021-6.

14 Cornelis RS, Neuhausen SL, Johansson O, Arason A, Kelsell D, Ponder BAJ, Tonin P, Hamann U, Lindblom A, Lalle P, Longy M, Olàh E, Scherneck S, Bignon YJ, Sobol H, Chang-Claude J, Larsson C, Spurr N, Borg A,
Barkardottir RB, Narod S, Devilee P, the Breast Linkage Consortium. High allele loss rates at $17 \mathrm{q} 12$-q21 in breast and ovarian tumors from BRCA1linked families. Genes Chrom Cancer 1995;13:203-10.

15 Presneau N, Laplace-Marieze V, Sylvain V, Lortholary A, Hardouin A, Bernard-Gallon D, Bignon YJ. New mechanism of BRCA-1 mutation by deletion/insertion at the same nucleotide position in three unrelated French breast/ovarian cancer families. Hum Genet 1998;103:334-9.

16 Laplace-Marieze V, Presneau N, Sylvain V, Kwiatkowski F, Lortholary A, Hardouin A, Bignon YJ. Systematic sequencing of the BRCA1 coding region for germ-line mutation detection in 70 French high-risk families. Int f Oncol 1999;14:971-7.

17 Vaurs-Barrière C, Vidal V, Penault-Llorca F, Kwiatkowski F, Maugard C, Bignon YJ. Pathology of sporadic breast tumors with $\mathrm{LOH}$ at the BRCA1 locus: correlation with histopathological features specific to familial BRCA1 tumors and absence of microsatellite instability. Int f Oncol 1998; 12:1373-8

18 Hoang JM, Cottu PH, Thuille B, Salmon RJ, Thomas G, Hamelin R. BAT26 , an indicator of the replication error phenotype in colorectal cancers and cell lines. Cancer Res 1997;57:300-3.

19 Zhou XP, Hoang JM, Li YJ, Seruca R, Carneiro F, Sobrinho-Simoes M, Lothe RA, Gleeson CM, Russell SE, Muzeau F, Flejou JF, Hoang-Xuan K, Lidereau R, Thomas G, Hamelin R. Determination of the replication error phenotype in human tumors without the requirement for matching normal DNA by analysis of mononucleotide repeat microsatellites. Genes Chrom Cancer 1998;21:101-7.

20 Kinzler KW, Vogelstein B. Gatekeepers and caretakers. Nature 1997;386: $761-2$ 